\title{
Research on Compulsory Drug Patent Licensing in China Under Covid-19
}

\author{
Zhou Zhide ${ }^{1, a^{*}}, \quad$ Yu Shanshan ${ }^{2, b}$ \\ ${ }^{1}$ Intellectual Property Research Institute, Xiamen University, Fujian 361005, China \\ ${ }^{2}$ School of Intellectual Property, Guilin University of Electronic Science and Technology, Guilin 541004, China \\ *Corresponding author. Email: 854167177@qq.com
}

\begin{abstract}
Covid-19 has spread in China and quickly spread to the world. The world health organization (WHO) has listed it as a public health emergency of international concern. In the face of this serious pandemic, global public security has been seriously threatened, and it is imperative to address the supply of medicines. This paper starts with the current situation of covid-19, compares the practice of compulsory drug patent licensing in different countries, and finds out the deficiency of compulsory drug patent licensing in China. Then put forward feasible suggestions for drug patent compulsory licensing.
\end{abstract}

Keywords: covid-19, drug patents, the compulsory license, the applicant, licensing procedures

\section{BACKGROUND}

Covid-19 first broke out in Hubei at the end of 2019, and then spread rapidly across the country. In the face of covid-19, domestic and foreign research institutions of medical institutions and pharmaceutical companies are actively researching and developing effective drugs and vaccines. Up to now, there are no drugs and vaccines for the prevention of covid-19. It is the most effective way to solve the pandemic prevention and control by finding effective drugs for novel coronavirus among existing drugs. The conflict between patented medicines and public health has become more pronounced during the covid-19 outbreak, and it is critical to resolve the issue between the two.

\section{COMPARISON OF CHINESE AND FOREIGN DRUG PATENT COMPULSORY LICENSE SYSTEM}

Compared with India, the two countries have similar compulsory licensing systems for drug patents, which can be applied by application or by authority. According to the patent law of India, the applicant can apply to the patent administration department for a certain drug patent on the basis of unreasonable price, failure to meet the needs of the society and failure to implement in the country. Compared with India, China lacks the condition of "no local implementation". According to the provisions of the Indian law, as long as it is not put into use in India, it is not implemented, which gives more discretion to the examination and approval of Indian patent. However, the time limit of implementation is stipulated in China, which increases the difficulty of implementation. The patent law of India does not limit the subject of compulsory drug patent license application, so it can be seen that the restrictive standard of this aspect in India is lower than that in Trips Agreement. In the case of endangering public security, Indian administrative departments can issue compulsory license orders according to their functions and powers within the scope permitted by law. In China, there are many restrictions on the application conditions and the subject of application. Compared with Brazil, China's compulsory licensing requirements for drug patents are more stringent. Brazil's industrial property law stipulates that the subject of the application includes not only the parties, but also the third party. In terms of burden of proof, China requires the applicant to provide proof, while Brazil transfers the burden of proof, obligation of explanation and responsibility of supervision to the patentee, which makes it easier to apply for compulsory patent license and creates a more favorable environment for implementation. Compared with the United States, the United States is a typical case law country with no clear "patent compulsory license system". However, the jurisprudence related to patent compulsory license in some judicial cases is also reflected in the Sherman Act. The United States has narrowed the scope of patent abuse, many acts are excluded from the scope of patent abuse, so the difficulty of compulsory patent licensing is much lower than in China.

\section{PROBLEMS WITH COMPULSORY DRUG PATENT LICENSING IN CHINA}

\subsection{The qualification of applicants is strict}

Stipulated in article 48 of the patent law in China, the main body of patent compulsory licensing is "for 
implementation of the unit or individual," examination and approval department is "the related administrative department for patent under the State Council". Compared with the Trips Agreement specified in the application subject "to users," the qualification to apply for standard definition is strict in our country. Of course, some countries have no restrictions on the subject of application. For example, article 93 of Japan's patent law and article 23 of Japan's utility model law stipulate that the subject of application for compulsory patent license in Japan can be the government or the person willing to implement the patent. Canadian patent law states that "anyone" can be the subject of an application. Article 11 of the patent law explains "implementation", and the implementation shall include five acts: manufacturing, using, promising to sell, selling and importing. Thus, it can be seen that the subject of application must be an enterprise that has the ability to import and export drugs. Because general pharmaceutical companies don't have "conditions" is rejected, the drug patent compulsory license cannot be implemented in our country.

\subsection{Complicated approval process}

In the Trips Agreement, the patent compulsory licensing examination is divided into judicial review and administrative examination. According to article 58 of the patent law, China adopts judicial review, and the examination and approval procedures are more complicated. Even in the emergency state of public health crisis, the examination and approval procedures have not been simplified. Due to the outbreak in the Chinese New Year, the large population movement led to the rapid spread of the disease. If it is not controlled in time, this pandemic will break out on a larger scale. The complicated examination and approval procedure makes the period of compulsory patent license prolonged, which is not conducive to the handling of pandemic situation in the state of emergency. The subject of examination and approval of compulsory patent license in China is the patent administration department under the state council, while drug production still needs the examination and approval of the drug regulatory department. Undoubtedly, this process increases the risk of an emergency and has adverse effects on public health.

\subsection{Patentee protection is lacking}

The drug development cycle is long and the cost is high. Under the condition of compulsory patent license, the cost of recovery for the patentee increases.In China's patent law and related legal norms, there is no clear compensation standard for compulsory drug patent license, and the protection of patentee is lacking. First of all, China's administrative law stipulates the principle of proportionality. If an individual loses his or her own interests due to the public interest, the state should make reasonable compensation to him or her. However, China's patent law does not clearly specify under what circumstances and to what extent he or she can get compensation for compulsory drug patent licensing. Secondly, after the subject of compulsory patent license has been approved, it may produce patented drugs in accordance with relevant regulations. However, the applicant's failure to comply with or not strictly comply with the regulations will cause a certain degree of loss to the patentee. It will cause the abuse of patented drugs and seriously threaten the legitimate rights and interests of the patentee.

\section{SUGGESTIONS ON COMPULSORY LICENSING OF DRUG PATENTS UNDER COVID-19}

\subsection{Set up the public health event emergency patent management system}

In response to public health emergencies, various regions of the country have launched emergency management responses and established crisis emergency management systems. In the course of pandemic prevention and control, patented drugs and supplies are needed. In order to solve the conflict between health rights and drug patent rights, a drug patent management system should be established on the basis of the national emergency management system, including the management of drug patent development, drug patent protection and drug patent management. In the emergency management system of drug patent, the public information sharing system of drug patent should be established. A collaborative management service platform for drug patents should be established to formulate specific management measures. Considering the root causes of conflicts, an emergency patent management system should be established to solve the conflicts. The government should make comprehensive use of the law to promote the rapid development of drug patents towards the direction of transformation and operation.

\subsection{Relax restrictions on applicants}

In order to better respond to covid-19 and better protect public health interests, China should relax the restrictions on compulsory drug licensing and reduce the restrictions on compulsory patent licensing. For this problem, we can refer to the Indian standard and classify the compulsory drug license according to its nature: general patent compulsory license, special patent compulsory license and import patent compulsory license. According to the nature of license for defining the sponsor and the applicant, the applicants' standard of India is low, any interest per person can be the applicant. The sponsors are limited by the requirements on the types of patents. The general patent compulsory license initiator can be any stakeholder, the 
special patent compulsory license initiator is required to be the central government of India, and the imported patent compulsory license initiator is required to be a country lacking or unable to solve public health problems. China may also classify the subject of application. The state may grant compulsory license qualifications to the subject that meets the requirements under emergency circumstances, provided that the relevant administrative procedures are complete.

\subsection{Simplify compulsory licensing procedures for patents}

China's regulation of patent compulsory licensing examination is judicial review. Compared with judicial review, administrative review will shorten the approval time. Due to the different nature of each drug and the different crisis situations, China can carry out administrative review under emergency circumstances to obtain compulsory license for patented drugs through faster review. In other cases, judicial review can better target drug manufacturers to maximize the public interest. The applicant shall be allowed to choose the application procedures that are favorable to him according to his own circumstances so as to facilitate the implementation of the compulsory patent license system. When making a decision on compulsory patent license, the loss caused by the patentee shall be reasonably compensated. The relevant laws and regulations of China have not been clearly stipulated. In this case, we can respect the autonomy of the parties and allow the parties to negotiate the fees through negotiation as far as possible so as to reach an agreement within the shortest time.

\subsection{Optimize the environment of drug patent compulsory license system implementation}

China's pharmaceutical enterprises started relatively late, and most of them are in the stage of imitation drugs. The government should fully realize the importance of compulsory patent licensing system and provide relevant guarantee for its smooth implementation. Government can make special policy, adding drug development special fund, provide loans for the pharmaceutical enterprises, introduce relevant drug research and development personnel, improve the overall strength of China's pharmaceutical industry. Pharmaceutical enterprises are drug producers of compulsory patent licensing system. Pharmaceutical enterprises should strengthen their comprehensive strength, improve their drug production capacity, and have sufficient capacity to meet social needs and ensure public health and safety. It is necessary to strengthen international cooperation and actively introduce foreign advanced systems and production lines to improve the development speed of Chinese pharmaceutical enterprises.

\section{CONCLUSION}

Drug production is crucial in the special period of the fight against covid-19, and the compulsory licensing system for drug patents is exactly the balance between the drug system and the patent system. If medical resources are not deployed in a timely manner, it is likely to damage the lives and health of the public and cause immeasurable losses. In the case of conflict between personal interests and public interests, China should face the current situation of the pandemic based on its national conditions. To the extent permitted by relevant international treaties, China can establish an emergency management system and improve the system of compulsory drug patent licensing. China should give full play to the value of compulsory drug patent licensing system so that China and the whole world can end the pandemic as soon as possible.

\section{ACKNOWLEDGMENT}

This work was supported by Guangxi Science and Technology Development Strategy Research Project (NO. ZL18077014)

\section{REFERENCES}

[1] Zhang Tian, Public Health Crisis to Discuss Drug Patent Compulsory License System from the Perspective, Journal of Medicine. 33(17) (2012) 37-38. DOI: 10.3969 / j.issn. 1006-1533.2012.17.015.

[2] Chen Qing, Variation and Countermeasures Against Compulsory Drug Patent Licensing Under the Provisions of TRIPS Agreement, Intellectual Property Rights. (6) (2013) 80-85. DOI: 10.3969/j.issn.1003-0476.2013.06.013.

[3] Liang Yu, Current Epidemic Situation, Further Discussion on the Dilemma of Compulsory Patent Licensing and Countermeasures, China Invention and $\begin{array}{llll}\text { Patent. } 17 & \text { (4)(2020)55-59. DOI: } 10.3969 \quad /\end{array}$ j.issn.1672-6081.2020.04.008.

[4] Guo, Current Situation of the Development of Chinese Patent Medicines and Reflect, Journal of Electronic Intellectual Property Rights. (8) (2019)57-65. DOI: 10.3969 / j.i ssn. 1004-9517.2019.08.007.

[5] Liu Huanan, From Bolar Defense Analyses our Country's Drug Research and Development of the Compulsory License System, Journal of Inventions and Patents in China. (5) (2019) 35 - 37. DOI: 10.3969 / j.i ssn. 1672-6081.2019.05.005.

[6] Li c f, Defects and Improvement of Compulsory Drug Patent Licensing System in China, Administration and Law. (2)2019. DOI: 10.3969 / j.issn.1007-8207.2019.02.014.35(02) (2017)146-151. 